\title{
Treatment of CNS Vasculitis in Children
}

\author{
Marinka Twilt, MD, $P h D^{1,2}$ \\ Susanne M. Benseler, MD, PhD ${ }^{1,2, *}$
}

\author{
Address \\ *,1Rheumatology, Department of Paediatrics, Alberta Children's Hospital, \\ University of Calgary, 2888 Shaganappi Trail NW, Calgary, AB, T3B 6A8, Canada \\ Email: susanne.benseler@albertahealthservices.ca \\ ${ }^{2}$ Cumming School of Medicine, University of Calgary, Calgary, AB, Canada
}

Published online: 17 0ctober 2015

(C) Springer International Publishing AG 2015

This article is part of the Topical Collection on Pediatric Rheumatology

Keywords Vasculitis · Neuroinflammation · Inflammatory brain disease · Treatment · Immunosuppression

\section{Opinion statement}

Inflammatory brain diseases, including childhood primary CNS vasculitis, are increasingly recognized disease entities. Mortality and morbidity have improved markedly due to rapid recognition and initiation of treatment. Treatment regimens are mostly derived from the adult literature. In this review, we summarize the most important adult and pediatric literature on therapy of primary CNS vasculitis. Evidence is all based on prospective or retrospective studies, as no trials have been performed in CNS vasculitis. Future new biomarker discoveries and increased knowledge on the pathophysiology are key for developing targeted treatment regimens.

\section{Introduction}

Primary angiitis of the central nervous system (PACNS) is an inflammatory disease of the cerebral blood vessels resulting in devastating neurological and psychiatric symptoms in previously healthy children [1-3]. First reported in 1959 in adults, the diagnosis was almost exclusively made on autopsy describing a granulomatous inflammation of the cerebral arteries [4]. In 1988, Calabrese [1] proposed diagnostic criteria for adults with PACNS including the following: newly acquired focal or diffuse neurological deficits plus angiographic or histological evidence of CNS vasculitis in the absence of a systemic condition that could explain or mimic these findings [1]. Over the past decade, these were modified and adopted for childhood PACNS (CPACNS) [5, 6].
Undoubtedly, the Calabrese criteria resulted in increased recognition and improved outcome of children and adults with primary CNS vasculitis. In addition, CNS vasculitis is increasingly recognized in the context of other illnesses such as infections, inflammatory or rheumatic diseases, immune dysregulations, malignancies, metabolic diseases, and other illnesses, commonly classifying it as secondary CNS vasculitis [7].

Cerebral vessel wall inflammation is the central, complex pathology in cPACNS. It is characterized by intramural and perivascular infiltration of immune cells, resulting in wall edema, vessel stenoses, endothelial activation and pro-thrombotic effects, perivascular brain tissue inflammation and irritation causing parenchymal 
dysfunction such as seizures and neuronal injury, critically decreased blood flow through the narrowed vessel, and the risk of ischemic injury to the vascular territory [8]. Treatment of CNS vasculitis aims to reverse the inflammation, the pro-thrombotic state, and acquired brain and/or spinal cord dysfunction. This review will provide an update of the current treatment approaches to primary and secondary CNS vasculitis in children. Treatment approaches differ between different disease subtypes and associated conditions.

\section{Childhood primary CNS vasculitis}

Inflammation of the CNS blood vessels and the perivascular space is the hallmark of childhood PACNS (CPACNS) [8]. Distinct subtypes have been identified based on the vessel size involved and course of inflammatory illness [5, 6]. Largemedium vessel CPACNS or angiography-positive cPACNS is an inflammatory vascular disease that can affect the intracranial internal carotid arteries (ICA), the circle of Willis and its branches, the posterior cerebral circulation, and the spinal vessels up to the resolution of 3-T magnetic resonance angiography and/or conventional angiography [5, 9]. This definition excludes small muscular arteries, arterioles, capillaries and venules, which are considered "small vessels of the brain." Therefore, by definition, small vessel cPACNS is an angiography-negative inflammatory brain disease [6]. Within a cerebral vessel, the distinction of proximal segments-defined as the first- and second-order branches-and distal segments-defined as any segments beyond second branching-is commonly made. Currently, four distinct subtypes of cPACNS are recognized, two affecting the large-medium vessels and two the small cerebral vessels $[5,6]$.

Nonprogressive CPACNS and progressive cPACNS are subtypes of angiography positive, large-medium cPACNS. Angiography-negative, biopsy-positive cPACNS consists of a subtype affecting the arterials and capillaries, which is commonly named "small vessel cPACNS" and an isolated cerebral venulitis. Each subtype has distinct presenting clinical features, laboratory findings, neuroimaging appearances, disease course, and prognosis. Each subtype has a distinct treatment approach. All treatment regimens are based on observational cohorts or case reports; no clinical trials have been conducted in primary CNS vasculitis [10, 11].

\section{Nonprogressive childhood primary angiitis of the central nervous system}

Nonprogressive cPACNS (NP-CPACNS) is the most common CNS vasculitis in children. It a monophasic, strictly unilateral inflammatory disease affecting the proximal vessel segments of the anterior and/or middle cerebral artery and or the intracranial segment of the ICA. NP-CPACNS is largely overlapping with conditions including "transient cerebral arteriopathy (TCA)" [12], "post-varicella angiopathy (PVA)" [13], and "focal cerebral arteriopathy (FCA)" [14]. Children with NP-CPACNS present with an acute onset of focal neurological deficits and arterial ischemic stroke [3]. This subtype is more commonly seen in boys. Presenting focal abnormalities may include hemiparesis, hemifacial weakness, aphasia, hemisensory loss, and unilateral deficits in fine motor skills $[3,5]$. Headaches are commonly reported, while diffuse deficits such as memory, behavior, or cognitive deficits are uncommon. Inflammatory markers including C-reactive protein (CRP) and erythrocyte sedimentation rate (ESR) 
are frequently normal [15]. Autoantibody testing is commonly negative; a small subgroup may have detectable anti-phospholipid antibodies. Importantly, von Willebrand factor antigen levels are commonly raised [16]. Cerebrospinal fluid (CSF) analysis is commonly normal with $\ll 50 \%$ of the children having a mildly raised white cell count (lymphocytes), mildly elevated protein level, or opening pressure. Bacterial and viral cultures remain negative. Polymerase chain reaction (PCR) and CSF: serum ratios for varicella zoster virus (VZV) antibody should be tested to identify an active infection [5]. MRI reveals diffusion-restricted lesions in a characteristic unilateral, anterior vascular distribution. Most commonly unilateral basal ganglia lesions are seen; however, any area of the anterior and/or middle cerebral artery territory may be affected [3] (Fig. 1). Angiography confirms unilateral inflammatory vessel wall disease of the proximal anterior and/or middle cerebral arteries and/or distal ICA with evidence of contrast wall enhancement [17]. Distal vessel segments are spared,
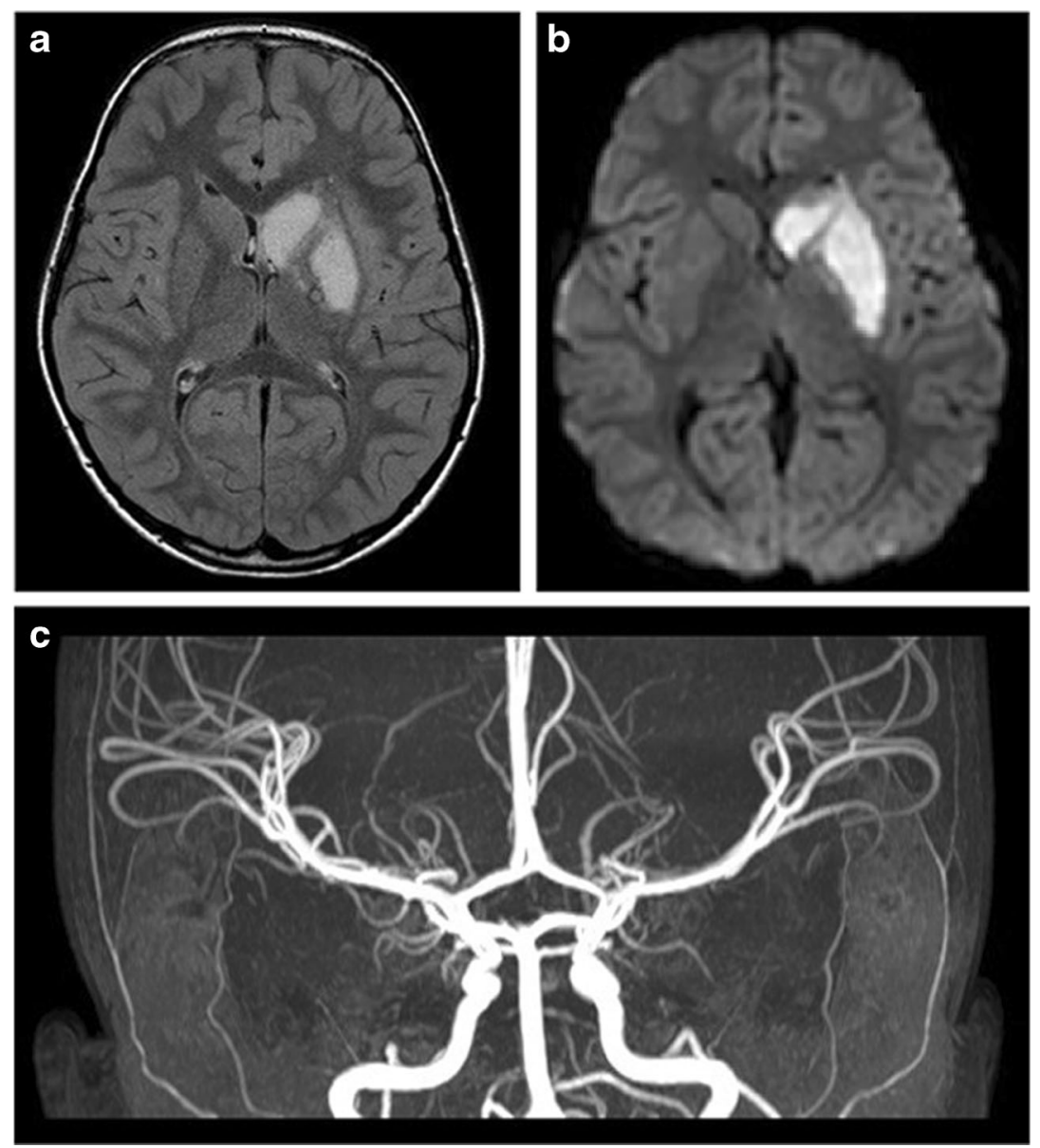

Fig. 1. Childhood primary nonprogressive CNS vasculitis in a 4-year-old boy presenting with vascular stroke and hemiparesis. Legend: The parenchymal imaging revealed lesions in the left middle cerebral artery (MCA) territory on T2/fluid attenuated inversion recovery (FLAIR) images (axial sequences, a). The corresponding diffusion-weighted images demonstrated decrease diffusion within the lesion representing a fresh stroke (axial sequences, $\mathbf{b}$ ). Vascular imaging revealed the vascular nature of the stroke: MRA time-of-flight identifies mildly narrowed, irregular proximal MCA segments (c). 
posterior circulation involvement is atypical, and spinal cord disease has not been reported in NP-PACNS [9]. The disease is a monophasic inflammatory disease and does not spread to other, previously unaffected, vascular territories; however, recurrent ischemic event can occur in the affected vascular territories when vessel wall inflammation persists. By definition, in NP-CPACNS, the suggested follow-up imaging at 3 months post-diagnosis does not reveal any new inflammatory vessel wall changes $[3,5]$.

\section{Treatment of nonprogressive childhood primary angiitis of the central nervous system}

Children with NP-cPACNS require anti-thrombotic therapy (see Tables 1 and 2) [35]. The optimal choice of anti-thrombotic medication may vary between patients depending on their vessel disease. The treatment aim is the prevention of recurrent ischemic event in the face of vessel stenosis, flow alteration, and endothelial cell activation [3]. Commonly, heparin, either conventional or low-molecular-weight (LMW), is primarily started. Anti-platelet agents are often introduced after 2 weeks and heparin is stopped. Some centers use antiplatelet agents up front in children with mild to moderate vessel stenosis. Highrisk patients including those with moderate-to-severe vessel stenosis, rapid progression of vascular narrowing, preexisting thrombi, or recurrent artery-toartery emboli may require ongoing LMW heparin, Coumadin, or even combination anti-thrombotic therapy. These approaches carry a higher risk of bleeding. In many centers, the monophasic inflammatory vessel wall disease in NPcPACNS is treated with a 3-month course of corticosteroids [11]. Typically, children receive IV methylprednisolone pulses for 3-7 days followed by oral prednisone at a dose of $2 \mathrm{mg} / \mathrm{kg}$, $\max 60 \mathrm{mg} /$ day as a single dose for a month with a taper over the subsequent 2 months (50, $40 \mathrm{mg}$ ). Vessel and parenchymal MRI imaging re-evaluation is recommended at the 3-month mark before discontinuing prednisone. Supplementary therapies should include vitamin D, calcium, and stomach protection, if required. Early, structured rehabilitation strategies appear to result in improved outcomes. The pediatric stroke outcome measure (PSOM) is a useful instrument to capture the functional status [36].

\section{Progressive childhood primary angiitis of the central nervous system}

Progressive CPACNS is a chronic inflammatory disease of the large-medium size vessels characteristically affecting both proximal and distal vessel segments [3]. The latter being the key differentiating factor from NP-CPACNS. Progressive cPACNS (P-CPACNS) can affect vessel in one or both hemispheres, involve the anterior and/ or posterior circulation, the brainstem, cerebellum, and spinal cord vasculature [3]. Children presenting with angiographic evidence of distal vessel segment vasculitis have a progressive disease course and therefore require combination immunosuppression [5]. Similar to NP-CPACNS, P-CPACNS more commonly affects boys than girls. Children with progressive P-CPACNS typically present with both focal and diffuse neurological deficits $[3,18]$. Headaches are present in $95 \%$ of PCPACNS patients. Any sensorimotor deficits can be seen, commonly hemisensory loss and fine or gross motor deficits; however, also movement abnormalities, seizures, speech, or vision problems can be seen. Difficulty in concentration, cognitive dysfunction, and mood and personality changes are frequently observed diffuse neurological deficits. The onset is often insidious [5]. Inflammatory markers in blood and CSF analysis are commonly abnormal, yet only mildly 
raised compared to levels in systemic vasculitides. Von Willebrand factor antigen is commonly raised [16]. Complement levels and immunoglobulin $\mathrm{G}$ levels may be elevated; specific antibodies are commonly negative. Characteristic MRI findings include both-ischemic and inflammatory lesions. Any pattern and distribution is possible; no "typical MRI appearance" of P-CPACNS exists [3]. Angiography reveals either unilateral or bilateral multifocal involvement of the proximal and distal segments of the cerebral arteries [9]. Thrombi and artery-to-artery embolism can be seen. Isolated vessel disease in the posterior circulation, brainstem, cerebellum, or spinal cord has been described. Hemorrhages are rare in childhood. Gadolinium contrast wall enhancement is seen in newly affected vascular segments $[17,37]$.

Table 1. Treatment of childhood primary CNS vasculitis

\begin{tabular}{|c|c|c|c|c|c|}
\hline Author & Nr patients & Age M/F & Diagnoses & Treatment & Outcome/course \\
\hline $\begin{array}{l}\text { Gallagher } \\
\text { et al. [18] }\end{array}$ & 5 children & $\begin{array}{c}\text { 5-11 years, } \\
2 \mathrm{M}, 3 \mathrm{~F}\end{array}$ & $\begin{array}{l}\text { PACNS angio } \\
\text { abnormal } 60 \% \text {, } \\
\text { MRA abnormal } \\
40 \% \text {, } \\
\text { no biopsy } \\
\text { CSF nl } 100 \%\end{array}$ & $\begin{array}{l}5 \text { Prednisone, } \\
4 \text { cyclophosphamide, } \\
1 \text { cyclophosphamide, } \\
\text { one dose }\end{array}$ & $\begin{aligned} 1 & =\text { lost-up } \\
1 & =\mathrm{nl} 2 \text { years } \\
3 & =\text { improving } \\
& \text { mild deficits } \\
& >1 \text { year follow-up }\end{aligned}$ \\
\hline $\begin{array}{l}\text { Lanthier } \\
\text { et al. [19] }\end{array}$ & 2 children & $\begin{array}{l}\text { 10-16 years, } \\
2 \mathrm{~F}\end{array}$ & $\begin{array}{l}\text { cPACNS small } \\
\text { vessel, biopsy } \\
\text { positive }\end{array}$ & $\begin{array}{l}2 \text { Prednisone, } \\
1 \text { cyclophosphamide }\end{array}$ & $\begin{array}{l}\text { One mild left } \\
\text { hemiparesis } \\
\text { after } 6 \text { years }\end{array}$ \\
\hline $\begin{array}{l}\text { Yaari } \\
\text { et al. [20] }\end{array}$ & 2 children & $\begin{array}{c}\text { 3-12 years, } \\
1 \mathrm{M}, 1 \mathrm{~F}\end{array}$ & $\begin{array}{l}\text { cPACNS small } \\
\text { vessel, biopsy } \\
\text { positive }\end{array}$ & $\begin{array}{l}2 \text { Prednisone, } \\
1 \text { cyclophosphamide, } \\
1 \text { methotrexate }\end{array}$ & $\begin{array}{l}\text { Relapse in both } \\
\text { patients }\end{array}$ \\
\hline $\begin{array}{l}\text { Benseler } \\
\text { et al. [6] }\end{array}$ & 4 children & $\begin{array}{l}\text { 5-16 years, } \\
4 \mathrm{~F}\end{array}$ & $\begin{array}{l}\text { SV-PACNS } \\
\quad \text { biopsy }+100 \%\end{array}$ & $\begin{array}{l}4 \text { Prednisone, } \\
4 \text { ASA, } \\
2 \text { cyclophosphamide, } \\
1 \text { azathioprine }\end{array}$ & $\begin{array}{l}\text { No relapse, } \\
\text { complete } \\
\text { neurologic } \\
\text { recovery }\end{array}$ \\
\hline $\begin{array}{l}\text { Benseler } \\
\text { et al. [5] }\end{array}$ & 62 children & $\begin{array}{l}0.5-17.5 \\
38 \mathrm{M}, 24 \mathrm{~F}\end{array}$ & $\begin{array}{l}\text { cPACNS angio } \\
\text { abnormal } \\
100 \%\end{array}$ & $\begin{array}{l}62 \text { ASA, } \\
21 \text { immunosuppressants }\end{array}$ & $\begin{array}{l}30 \% \text { Progressive } \\
\text { cPACNS }\end{array}$ \\
\hline $\begin{array}{l}\text { De Tiege } \\
\text { et al. [21] }\end{array}$ & 3 children & $\begin{array}{c}\text { 9-15 years, } \\
2 \mathrm{M}, 1 \mathrm{~F}\end{array}$ & $\begin{array}{l}\text { SV PACNS, } \\
\text { biopsy positive }\end{array}$ & $\begin{array}{l}3 \text { Prednisone, } \\
3 \text { cyclophosphamide }\end{array}$ & $\begin{array}{l}1 \text { long-term } \\
\text { relapse } 8 \text { years } \\
\text { later; } \\
\text { all no deficits }\end{array}$ \\
\hline $\begin{array}{l}\text { Bitter } \\
\text { et al. [22] }\end{array}$ & 2 children & $\begin{array}{l}\text { 5-7 years, } \\
2 \mathrm{~F}\end{array}$ & $\begin{array}{l}\text { PACNS, } \\
1 \text { MRA abnormal, } \\
1 \text { biopsy abnormal }\end{array}$ & $\begin{array}{l}2 \text { Prednisone, } \\
2 \text { cyclophosphamide }\end{array}$ & $\begin{array}{l}1 \text { relapse both } \\
\text { remission }\end{array}$ \\
\hline $\begin{array}{l}\text { Sen et al. } \\
\text { [23] }\end{array}$ & $\begin{array}{l}3 \text { children } \\
\text { (three centers) }\end{array}$ & $\begin{array}{r}\text { 5-9 years, } \\
1 \mathrm{M}, 2 \mathrm{~F}\end{array}$ & $\begin{array}{l}\text { PACNS, } \\
1 \text { MRA abnormal, } \\
1 \text { biopsy abnormal, } \\
1 \text { MRI abnormal }\end{array}$ & $\begin{array}{l}3 \text { Prednisone, } \\
2 \text { cyclophosphamide, } \\
1 \text { methotrexate }\end{array}$ & $\begin{array}{l}2 \text { relapses in } \\
\text { one patient }\end{array}$ \\
\hline $\begin{array}{l}\text { Hutchinson } \\
\text { et al. [10] }\end{array}$ & 19 children & $\begin{array}{c}5-17.5 \text { years, } \\
4 \mathrm{M}, 15 \mathrm{~F}\end{array}$ & SV-CPACNS & $\begin{array}{l}19 \text { Prednisone, } \\
19 \text { cyclophosphamide } \\
\text { Maintenance: } \\
9 \text { azathioprine, } \\
5 \text { MMF }\end{array}$ & $\begin{array}{l}8 / 19 \text { relapse } \\
4 / 19 \text { remission } \\
\text { of medication }\end{array}$ \\
\hline
\end{tabular}




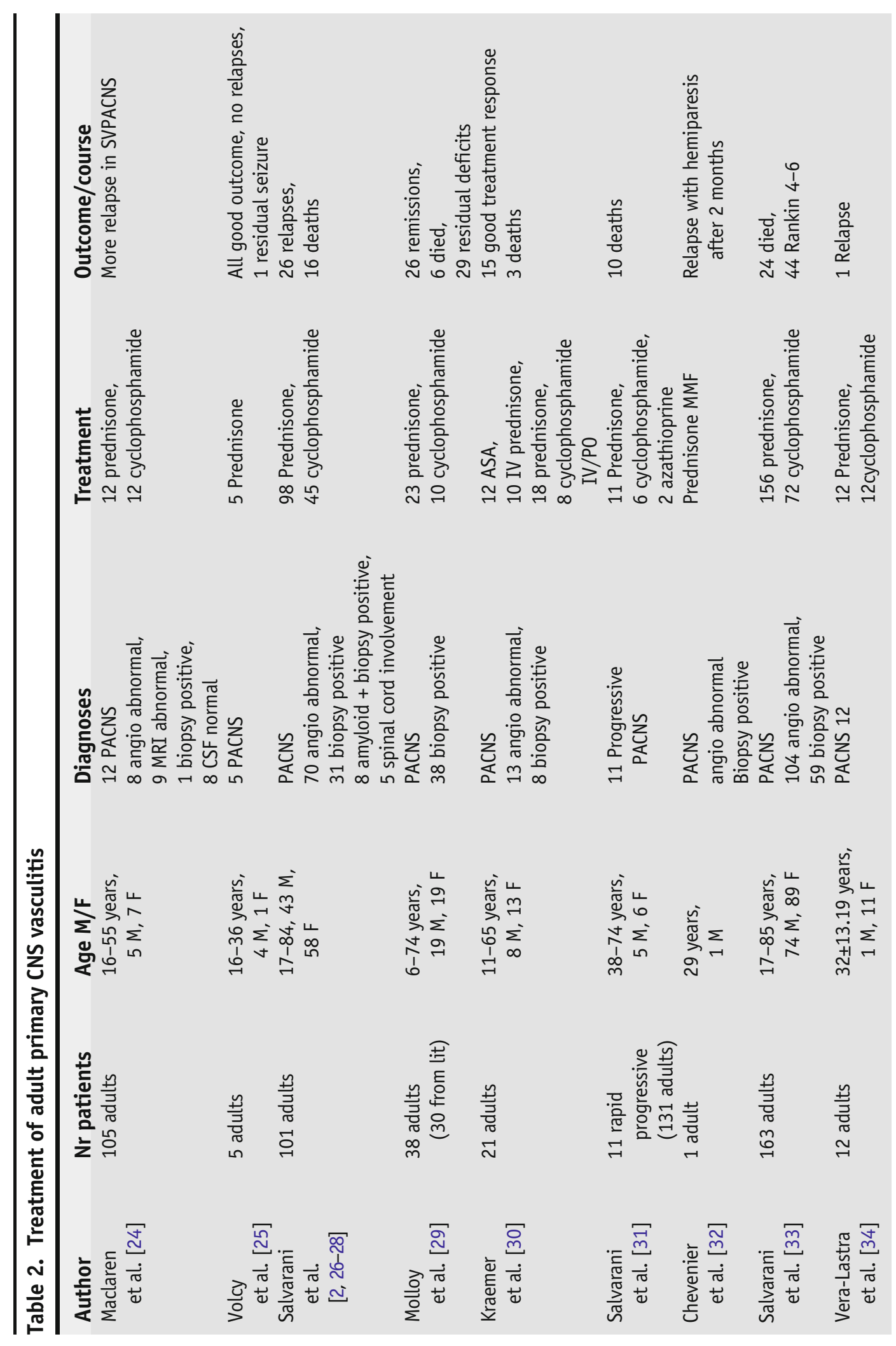


Follow-up imaging in untreated children commonly documents the spread of the disease with new inflammatory vessel wall changes.

\section{Treatment of progressive childhood primary angiitis of the central nervous system}

Similar to NP-CPACNS, children with P-CPACNS require anti-thrombotic therapy (see Tables 1 and 2). In many centers, heparin is the preferred first-line medication followed by anti-platelet drugs. Some primarily start antiplatelet agents to prevent recurrent ischemic event secondary to endothelial cell activation resulting from vessel wall inflammation. All children with P-CPACNS require immunosuppression, most commonly after 3-7 days of IV methylprednisolone pulses (30 mg/kg, max $1 \mathrm{~g})$; high-dose oral prednisone $(2 \mathrm{mg} / \mathrm{kg}$, max $60 \mathrm{mg}$ /day) is combined with monthly IV cyclophosphamide [5, 18, 22, 35]. Commonly, cyclophosphamide induction therapy is given over 6 months (seven doses, $500 \mathrm{mg} / \mathrm{m}^{2}$ plus Mesna) and is followed by oral maintenance treatment with either mycophenolate mofetil (MMF, $800-1200 \mathrm{mg} / \mathrm{m}^{2} /$ day) or azathioprine ( $2 \mathrm{mg} / \mathrm{kg} /$ day) for 18 months [5, 18]. Supplementary therapies should include pneumocystis prophylaxis while receiving cyclophosphamide, vitamin D, calcium, and stomach protection, if required. Early rehabilitation strategies may improve outcomes; however, residual focal neurological deficit is more often seen in this subtype. Monitoring of treatment effectiveness commonly includes serial functional clinical testing (PSOM), von Willebrand factor antigen (vWF) levels, cognitive testing yearly, and six monthly MRI/A studies. Follow-up is best provided in an interdisciplinary team. Children with refractory P-cPACNS may benefit from anti-TNF alpha therapy with monthly infliximab for 24 months [38].

\section{Small vessel childhood primary angiitis of the central nervous system}

Angiography-negative, small vessel cPACNS is the most challenging subtype due to its clinical heterogeneity, the exponential risk of severe brain injury due to frequently disease-associated seizures, the lack of specific biomarkers, and the need for invasive brain biopsies to confirm the diagnosis $[6,10]$. Disease and treatment result in a very high burden for patients and families. Small vessel cPACNS has a female predominance. Children often present with an insidious onset of cognitive deficits, headaches, and seizures. Constitutional symptoms may be present; leading clinical features of meningitis, optic neuritis, or transverse myelitis can be seen [39]. Eight of ten children with small vessel vasculitis present with seizures-most commonly generalized. Refractory seizure status is a well-recognized presentation of small vessel vasculitis and mandates a rapid evaluation. Blood inflammatory markers are commonly raised in children with small vessel CPACNS; the elevation may be modest though [10]. vWF antigen strongly supports a vasculitic etiology as opposed to demyelinating or other conditions; $90 \%$ of children have abnormal CSF studies at diagnosis including increased protein level and/or leukocytosis [16]. The MRI is a sensitive, yet nonspecific test for small vessel cPACNS. The vast majority has T2/FLAIRpositive, not diffusion-restricted MRI abnormality lesions in variable distributions [6]. Lesions can affect all matters, may be unifocal or multifocal, symmetrical, or asymmetrical, and may enhance contrast. Atypical appearances including ring enhancement, mass lesions, and hemorrhages have been documented [40]. Focal or diffuse meningeal enhancement is characteristic for small 
vessel vasculitis, when untreated. Repeatedly normal MRIs have been documented in children presenting with status epilepticus. By definition, MRA and conventional angiography studies are normal in children with small vessel cPACNS. Lesional brain biopsy should target new, accessible areas [8]. Distinctly different from experience in adult CNS vasculitis, nonlesional approaches have similar diagnostic yields due to the diffuse, nonpatchy nature of the disease in children $[4,8,41]$. Intramural and perivascular lymphocytic infiltrates predominantly consisting of CD8-positive T cells are the hallmark of childhood small vessel vasculitis [8]. Distinctly different from adult PACNS brain biopsies, granulomatous inflammation or neutrophilic infiltrates with fibrinoid necrosis are absent in children with cPACNS $[2,7]$. Small vessel CPACNS is a chronic disease with highly variable speed of progression and fluctuation in disease activity even when untreated that remain unexplained. Prolonged time to diagnosis and the presence of seizures were found to impair recovery dramatically and result in severe cognitive deficits [10].

\section{Treatment of small vessel childhood primary angiitis of the central nervous system}

Combination immunosuppressive therapy should be initiated rapidly; delay to therapy may result in a higher risk for irreversible brain injury. Similar to the PcPACNS regimen, a 6-month induction treatment with intravenously cyclophosphamide $\left(500 \mathrm{mg} / \mathrm{m}^{2}\right)$ plus corticosteroids (methylprednisolone pulses $30 \mathrm{mg} / \mathrm{kg}$, max $1000 \mathrm{mg}$ for 3-7 days followed by daily oral prednisone $2 \mathrm{mg} / \mathrm{kg}$, $\max 60 \mathrm{mg} /$ day) is followed by 18 months of maintenance treatment; MMF was found to be superior to azathioprine (see Tables 1 and 2) [10]. Recent series report the effective primary use of MMF $[32,33]$. Supplementary therapies including pneumocystis prophylaxis while on cyclophosphamide, vitamin $\mathrm{D}$, calcium, and stomach protection should be considered. At 24 months, $70 \%$ of the children were found to have a good functional neurological outcome by PSOM [10]. The key concern remains the cognitive outcome of children with small vessel cPACNS, in particular when initially presenting with prolonged seizures. Most children receive antiepileptic drugs for years [10].

\section{Secondary CNS vasculitis}

\section{Secondary CNS vasculitis associated with infection}

The most common etiology for secondary vasculitis is infection [42]. CNS vasculitis can be mimicked by many infections; therefore, it is necessary to include a complete infectious workup. PCR of serum and CSF can identify most infections [42]. Varicella zoster virus (VZV) is a notorious mimic of CNS vasculitis and is known as post-varicella angiopathy (PVA) [13, 43]. A wide variety of cell types in the central and peripheral nervous system can be infected by VZV [44]. PVA is a reactivation of VZV that causes inflammatory stenoses of the proximal large vessels [44-46]. Signs of CNS vasculitis have been noted to be present in adult patients with human immunodeficiency virus (HIV), with on brain biopsy only evidence of HIV [47]. Many other viruses, bacteria, and fungal infections can cause secondary CNS vasculitis. Patients with HIV can also develop secondary CNS vasculitis based on infections due to immune reconstitution syndrome (IRIS) [48]. IRIS develops usually in the first 2 months after start of antiretroviral therapy. IRIS has been linked with several types of 
infections or inflammation including the following: cytomegalovirus (CMV), cryptococcal meningitis, hepatitis B and $\mathrm{C}$, herpes zoster and herpes simplex, Mycobacterium avium complex (MAC), and viral brain infections causing progressive multifocal leukoencephalopathy (PML) [48]. IRIS can be treated by prednisone while continuing antiretroviral therapy, allowing the immune system to recover while treating the inflammation [48].

\section{Secondary CNS vasculitis in rheumatic diseases}

In rheumatic diseases, secondary CNS vasculitis may develop during or may even be the presenting symptom [49]. Involvement of the CNS is more commonly seen in adults with rheumatic diseases but can be seen in children with ANCA-associated vasculitis, such as granulomatosis with polyangiitis (GPA, previously known as Wegener granulomatosis) and microscopic polyangiitis (MPA), polyarteritis nodosa (PAN), Takayasu arteritis, and systemic lupus erythromatosus (SLE) [49-53] (Fig. 2). Treatment of CNS manifestations in rheumatic diseases is mostly done with corticosteroids and cyclophosphamide, in agreement with the treatment for primary CNS vasculitis [54].

\section{Secondary CNS vasculitis in systemic inflammatory diseases}

Secondary CNS vasculitis is increasingly recognized in systemic diseases; it may be the primary symptom or complication of hemophagocytic lymphohistiocytosis (HLH), Kawasaki disease, inflammatory bowel disease, or systemic immunedysregulations [55, 56].

HLH is a rare but potentially fatal disease of nonmalignant but overactive histiocytes and lymphocytes commonly triggered by an infection. The clinical picture of HLH includes fever, hepatosplenomegaly, pancytopenia,

hyperferritinemia, raised liver enzymes, and hypertriglyceridemia [57, 58]. CNS vasculitis is well described in children with HLH $[56,59]$ (Fig. 3). An increasing
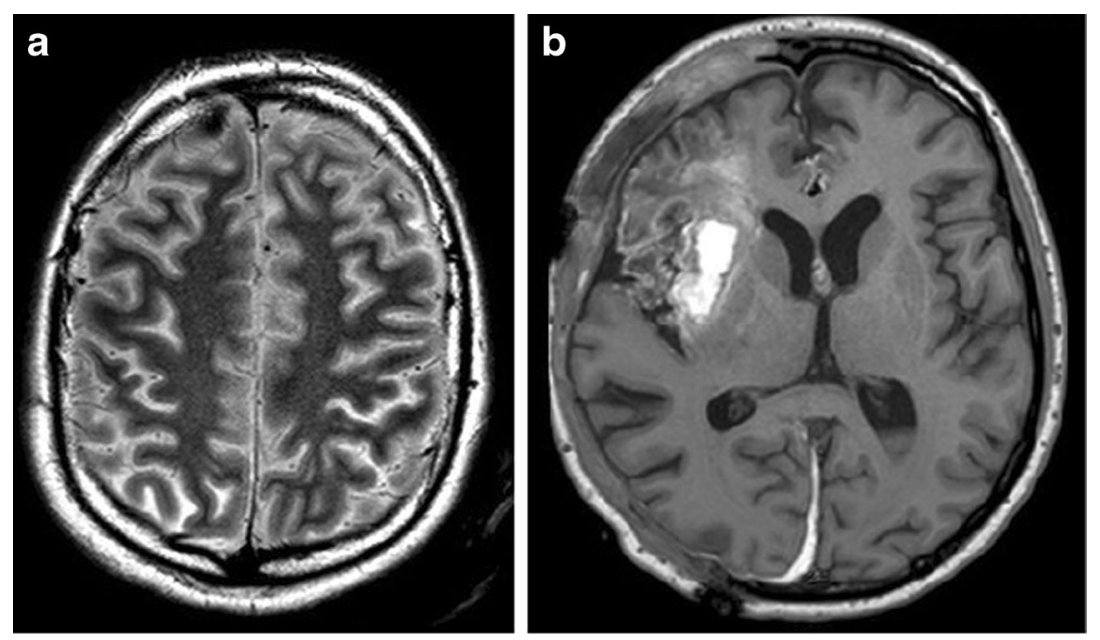

Fig. 2. Secondary CNS vasculitis in a 14-year-old girl with systemic lupus erythematosus complicated by macrophage activation syndrome. Legend: The parenchymal imaging revealed thickening of the meninges in the absence of significant parenchymal lesions on T2/fluid attenuated inversion recovery (FLAIR) images (axial sequences, a). With progression of the inflammatory process and the HLH-associated cytopenia lesions extended into the parenchyma causing hemorrhages and mass effect and requiring a craniectomy (b). 


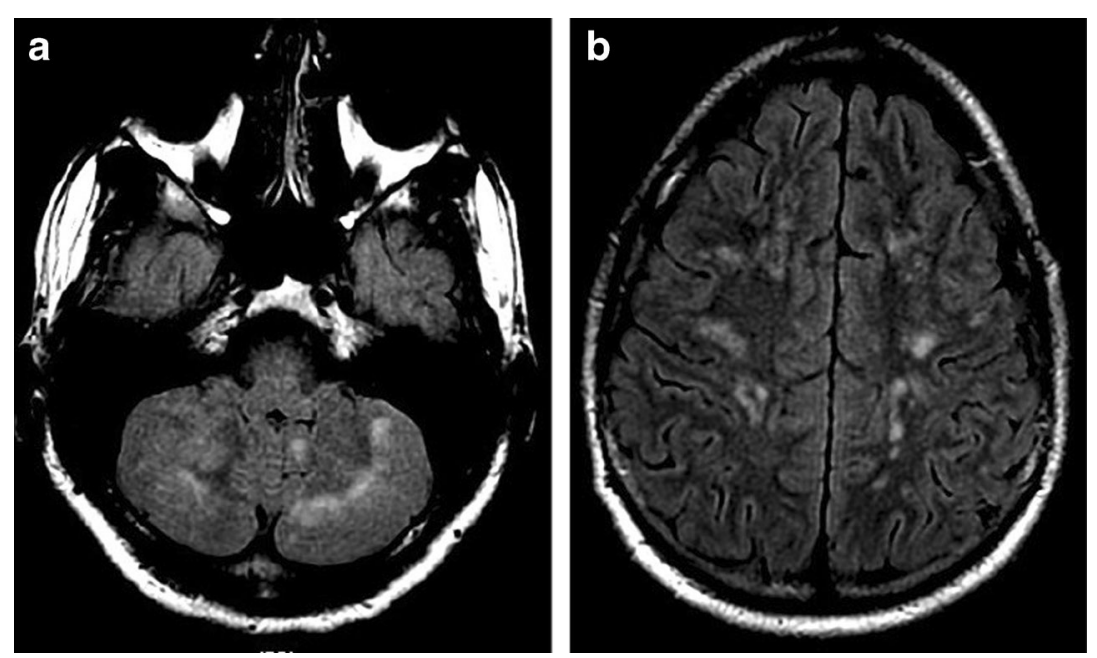

Fig. 3. Secondary CNS vasculitis in a 17-year-old teenager with Griscelli syndrome and hemophagocytic lymphohistiocytosis (HLH). Legend: The parenchymal imaging revealed ill-defined lesions in the cerebellum (Fig. 3a) and in the white matter of both hemispheres (Fig. 3b) on T2/fluid attenuated inversion recovery (FLAIR) images (axial sequences). Vascular imaging including MRA and conventional angiography was normal. The brain biopsy revealed a small vessel CNS vasculitis with a predominant macrophage infiltrate (not shown); genetic testing confirmed a RAB 27A gene mutation characteristic for Griscelli syndrome type 2.

list of immune dysregulations is reported to carry a potential higher risk of CNS vasculitis and HLH including X-linked lymphoproliferative disease type 1 (XLP1) with mutations in SH2 domain protein 1A (SH2D1A), X-linked immunodeficiency with magnesium defect, EBV infection and neoplasia (XMEN), Hermansky-Pudlak syndrome, chronic granulomatous disease (CGD), and idiopathic hypereosinophilic syndrome (IHES). Secondary HLH typically occurs in children with severe infections, malignancies, or rheumatologic diseases most commonly in those with systemic juvenile idiopathic arthritis or lupus. The treatment of CNS vasculitis in primary or secondary HLH follows the Histiocyte Society treatment protocol (HLH-94) including dexamethasone in combination with cyclosporine and VP-16[60]. Intrathecal MTX is added in selected patients. Kawasaki disease is a systemic inflammatory disease accompanied by vasculitis, mainly involving the coronary arteries. Inflammation of the cerebral blood vessels has been reported in Kawasaki; post-mortem brain examinations may reveal leptomeningeal thickening, endarteritis, and periarteritis [61]. Children with organ-specific inflammatory disease such as inflammatory bowel disease can present with CNS vasculitis [62]. Granulomatous vessel wall inflammation resulting in strokes and hemorrhages has been reported [63, 64].

\section{Secondary CNS vasculitis in other systemic diseases/exposures}

Secondary CNS vasculitis can also be caused by drugs, such as cocaine and amphetamines; however, these are also capable of mimicking CNS vasculitis without an inflammatory component but a vasoconstrictive component [65]. Secondary CNS vasculitis in form of radiation-induced arteritis has been described in patients after radiation therapy [66]. In children, who were treated for malignancies, CNS vasculitis has been seen in graft versus host disease $[67,68]$. 
Newly recognized diseases such as early-onset stroke and vasculopathy associated with mutations in adenosine deaminase 2 (ADA2) and activated stimulator of interferon genes (STING)-associated vasculopathy with onset in infancy (SAVI) are both mimics of CNS vasculitis [69-71]. ADA2 mutations have also been described in children with a polyarteritis nodosa [70]. Treatment with etanercept has been successful in patients with ADA2 mutations [69]. JAK inhibitors have been shown to be effective in vitro in SAVI [71].

Aicardi-Goutieres syndrome (AGS) can also mimic secondary CNS vasculitis. In a significant minority of AGS patients, problems start in utero and this form is associated with mutations in TREX1, RNASEH2A, and RNASEH2C [72]. More frequently, a late-onset presentation of AGS is seen. This form is associated with mutations in RNASEH2B, SAMHD1, and ADAR1 [72]. The clinical phenotype of the late-onset presentation may be associated with a lesser degree of neurological dysfunction. AGS can be difficult to distinct due to the fact that neurological dysfunction is not always severe, microcephaly is not invariable, onset is not always in the first year of life, white matter changes and calcifications are not inevitable, and CSF lymphocytosis can be absent [72, 73]. AGS is associated with increased levels of interferon alpha in the CSF and serum. Treatment of AGS has been empirical and has included many of the immunemodulatory treatments [72].

\section{Approach to treatment secondary CNS vasculitis}

The identification and rapid management of the underlying condition are crucial in controlling secondary CNS vasculitis. This includes anti-microbial therapy and targeted approaches toward systemic inflammation and immune dysregulation. Immunosuppressive therapies for cerebral vessel inflammation are commonly either started, modified, or their dose adjusted.

\section{Corticosteroids}

Steroids are the first-line therapeutic option children with secondary CNS vasculitis. They have an acute onset of action in the CNS diseases, which may be partially explained by their ability to close the blood-brain barrier and thus reducing inflammation [74]. The typical treatment dose of IV methylprednisolone for acute CNS inflammation is 15 to $30 \mathrm{mg} / \mathrm{kg}$ of body weight given intravenously [10]. Dexamethasone is an alternative treatment option and may have better CNS penetration [60]. After 3-5 days of high-dose intravenous therapy, often, patients are then switched to high-dose oral corticosteroids with a slow taper over weeks. Abrupt withdrawal is avoided after long dosing schedules because of the suppression of endogenous cortisol production.

\section{Intravenous immunoglobulin}

Intravenous immunoglobulin (IVIG) is frequently used in secondary CNS vasculitis, in particular when associated with infection [75]. IVIGs can be used acutely not only because of their rapid onset of action, but also as part of chronic therapy. Effects can last weeks or months; however, they may lose effectiveness in some cases with chronic use. The typical acute treatment dose is a total of $2 \mathrm{~g} / \mathrm{kg}$ of body weight divided over 2 to 5 days. Chronic recurrent 
treatments usually consist of a $1 \mathrm{~g} / \mathrm{kg}$ dose given over 1 day. Alternate-week dosing with IVIG is reasonable since the elimination half-life of human immunoglobulins is approximately $2-3$ weeks.

\section{Plasmapheresis/exchange}

Plasmapheresis is frequently used in catastrophic, live-threatening inflammation including involvement of the brainstem and spinal cord. PE requires largebore intravenous access and special procedural center expertise. There is limited published evidence for its efficacy [76]. A typical treatment course is 5 to 7 exchanges spaced out over 5-10 days [54].

\section{Rituximab}

Rituximab is a chimeric monoclonal antibody that targets the CD20 surface antigen and causes a rapid loss of CD20-positive B cells from the circulation. The circulating B cell population reconstitutes from memory B cell pools and nascent B cells. The typical dose is $375 \mathrm{mg} / \mathrm{m}^{2}$ intravenously every 2 weeks for two doses. Follow-up cycles are prescribed depending on the response. Side effects of RTX may include those typically seen with infusions such as hypotension, flushing, headache, pruritus, fever, nausea, and fatigue [77]. Rare cases of associated progressive multifocal leukoencephalopathy (PML) have been reported [78].

\section{Cyclosporin A}

Cyclosporin A (CSA), a cyclic nonribozomal peptide, and FK506, a macrolide immune suppressor, act through similar mechanisms by calcineurin inhibition, which prevent $\mathrm{T}$ lymphocyte activation. They are often considered interchangeable, but patients with side effects on one can often be switched to the other with good effect. The oral dose can be titrated up to $5 \mathrm{mg} / \mathrm{kg} /$ day divided twice daily [79]. Levels are checked exactly $12 \mathrm{~h}$ after the last dose because of erratic absorption. Side effects may include hypertension, renal/hepatic toxicity, tremor, and gastrointestinal complaints.

\section{Mycophenolate mofetil}

Mycophenolate mofetil (MMF) is a reversible inhibitor of inosine monophosphate dehydrogenase, in the purine metabolism. It reduces $\mathrm{B}$ and $\mathrm{T}$ lymphocyte proliferation. The dose is titrated up to $600 \mathrm{mg} / \mathrm{m}^{2}$ given orally twice a day with a maximum daily dose of $2 \mathrm{~g}$ [10]. Side effects may include diarrhea, headache, elevated liver transaminases, and bone marrow suppression. Rare cases of PML have been reported with this medication in adults and children after renal transplant [80].

\section{Cyclophosphamide}

Cyclophosphamide (CP) is an alkylating agent that causes DNA interstrand crosslinkage and reduces lymphocyte proliferation. It is generally reserved for refractory diseases because of its long-term concerns for secondary malignancies and sterility. This medication is most commonly used in severe vasculitis 
conditions. The dose is generally monthly $750-1000 \mathrm{mg} / \mathrm{mg}^{2}$ intravenous pulse given for $6-12$ months $[10,54]$. The dose is titrated to cause a white blood cell count nadir of approximately 1500-2000. Mesna and prehydration can be given to decrease side effects.

Objective improvements which translate into meaningful gains in functional abilities, such as a return to school or resumption of independent daily living, should prompt consideration of a long-term plan for immunotherapy for that patient, since most patients will have a relapse of their symptoms on withdrawal of acute therapies. General guiding principles include maintenance of remission and a reduction in corticosteroid or IVIG dependence whenever possible. Some patients remain corticosteroid or IVIG dependent, despite optimization of oral immunosuppressant therapy.

\section{Supportive therapy}

Adjunctive therapy is frequently required to manage concomitant seizure disorders and psychotic symptoms. Additional treatment with Pneumocystisjirovecii prophylaxis while on $\mathrm{CP}$ or rituximab and vitamin $\mathrm{D}$ and calcium plus gastric protection while on high-dose steroids is required.

Beyond the medical treatment, early rehabilitation, including physiotherapy, occupational therapy, and cognitive therapy, is required to optimize the long-term outcome.

Overall, diagnosing primary CNS vasculitis remains difficult and the spectrum of secondary CNS vasculitis and mimics is rapidly expanding. Physicians should be aware of new disease entities, and an extensive workup is mandatory. Increased recognition and prompt accurate treatment of CNS vasculitis have led to a significant decreased mortality and improved morbidity.

\section{Compliance with Ethics Guidelines}

\section{Conflict of Interest}

Marinka Twilt and Susanne M. Benseler declare that they have no conflict of interest.

Human and Animal Rights and Informed Consent

This article does not contain any studies with human or animal subjects performed by any of the authors.

\section{References and Recommended Reading}

1. Calabrese LH, Mallek JA. Primary angiitis of the central nervous system. Report of 8 new cases, review of the literature, and proposal for diagnostic criteria. Medicine (Baltimore). 1988;67(1):20-39.

2. Salvarani C, Brown Jr RD, Calamia KT, Christianson TJ, Weigand SD, Miller DV, et al. Primary central nervous system vasculitis: analysis of 101 patients. Ann Neurol. 2007;62(5):442-51.

3. Aviv RI, Benseler SM, Silverman ED, Tyrrell PN, Deveber G, Tsang LM, et al. MR imaging and angiography of primary CNS vasculitis of childhood. AJNR Am J Neuroradiol. 2006;27(1):192-9. 
4. Lie JT. Primary (granulomatous) angiitis of the central nervous system: a clinicopathologic analysis of 15 new cases and a review of the literature. Hum Pathol. 1992;23(2):164-71.

5. Benseler SM, Silverman E, Aviv RI, Schneider R, Armstrong D, Tyrrell PN, et al. Primary central nervous system vasculitis in children. Arthritis Rheum. 2006;54(4):1291-7.

6. Benseler SM, deVeber G, Hawkins C, Schneider R, Tyrrell PN, Aviv RI, et al. Angiography-negative primary central nervous system vasculitis in children: a newly recognized inflammatory central nervous system disease. Arthritis Rheum. 2005;52(7):2159-67.

7. Twilt M, Benseler SM. The spectrum of CNS vasculitis in children and adults. Nat Rev Rheumatol. 2012;8(2):97-107.

8. Elbers J, Halliday W, Hawkins C, Hutchinson C, Benseler SM. Brain biopsy in children with primary small-vessel central nervous system vasculitis. Ann Neurol. 2010;68(5):602-10.

9. Aviv RI, Benseler SM, DeVeber G, Silverman ED, Tyrrell PN, Tsang LM, et al. Angiography of primary central nervous system angiitis of childhood: conventional angiography versus magnetic resonance angiography at presentation. AJNR Am J Neuroradiol. 2007;28(1):9-15.

10. Hutchinson C, Elbers J, Halliday W, Branson H, Laughlin S, Armstrong D, et al. Treatment of small vessel primary CNS vasculitis in children: an open-label cohort study. Lancet Neurol. 2010;9(11):1078-84.

11. Soon GS, Yau I, Branson H, DeVeber G, Laughlin S, Benseler SM. Non-progressive primary CNS vasculitis in children: immunosuppression reduces recurrent ischemic event risk. Arthritis Rheum. 2008;9:S942.

12. Sebire G. Transient cerebral arteriopathy in childhood. Lancet. 2006;368(9529):8-10.

13. Lanthier S, Armstrong D, Domi T, deVeber G. Postvaricella arteriopathy of childhood: natural history of vascular stenosis. Neurology. 2005;64(4):660-3.

14. Bernard TJ, Manco-Johnson MJ, Lo W, MacKay MT, Ganesan V, DeVeber G, et al. Towards a consensusbased classification of childhood arterial ischemic stroke. Stroke. 2012;43(2):371-7.

15. Cellucci T, Tyrrell PN, Twilt M, Sheikh S, Benseler SM. Distinct phenotype clusters in childhood inflammatory brain diseases: implications for diagnostic evaluation. Arthritis Rheumatol. 2014;66(3):750-6.

16. Cellucci T, Tyrrell PN, Pullenayegum E, Benseler SM. von Willebrand factor antigen-a possible biomarker of disease activity in childhood central nervous system vasculitis? Rheumatology (Oxford).

2012;51(10):1838-45.

17. Kuker W, Gaertner S, Nagele T, Dopfer C, Schoning M, Fiehler J, et al. Vessel wall contrast enhancement: a diagnostic sign of cerebral vasculitis. Cerebrovasc Dis. 2008;26(1):23-9.

18. Gallagher KT, Shaham B, Reiff A, Tournay A, Villablanca JP, Curran J, et al. Primary angiitis of the central nervous system in children: 5 cases. J Rheumatol. 2001;28(3):616-23.

19. Lanthier S, Lortie A, Michaud J, Laxer R, Jay V, deVeber G. Isolated angiitis of the CNS in children. Neurology. 2001;56(7):837-42.

20. Yaari R, Anselm IA, Szer IS, Malicki DM, Nespeca MP, Gleeson JG. Childhood primary angiitis of the central nervous system: two biopsy-proven cases. J Pediatr. 2004;145(5):693-7.

21. De Tiege X, Van Bogaert P, Aeby A, Salmon I, Parpal H, Poppe AY, et al. Primary angiitis of the central nervous system: neurologic deterioration despite treatment. Pediatrics. 2011;127(4):e1086-90.

22. Bitter KJ, Epstein LG, Melin-Aldana H, Curran JG, Miller ML. Cyclophosphamide treatment of primary angiitis of the central nervous system in children: report of 2 cases. J Rheumatol. 2006;33(10):2078-80.

23. Sen ES, Leone V, Abinun M, Forsyth R, Ramesh V, Friswell $\mathrm{M}$, et al. Treatment of primary angiitis of the central nervous system in childhood with mycophenolate mofetil. Rheumatology (Oxford). 2010;49(4):806-11.

24. MacLaren K, Gillespie J, Shrestha S, Neary D, Ballardie FW. Primary angiitis of the central nervous system: emerging variants. QJM. 2005;98(9):643-54.

25. Volcy M, Toro ME, Uribe CS, Toro G. Primary angiitis of the central nervous system: report of five biopsyconfirmed cases from Colombia. J Neurol Sci. 2004;227(1):85-9.

26. Salvarani C, Brown Jr RD, Calamia KT, Christianson TJ, Huston 3rd J, Meschia JF, et al. Primary central nervous system vasculitis presenting with intracranial hemorrhage. Arthritis Rheum. 2011;63(11):3598-606.

27. Salvarani C, Brown Jr RD, Calamia KT, Christianson TJ, Huston 3rd J, Meschia JF, et al. Primary CNS vasculitis with spinal cord involvement. Neurology. 2008;70(24 Pt 2):2394-400.

28. Salvarani C, Brown Jr RD, Calamia KT, Christianson TJ, Huston 3rd J, Meschia JF, et al. Primary central nervous system vasculitis: comparison of patients with and without cerebral amyloid angiopathy. Rheumatology (Oxford). 2008;47(11):1671-7.

29. Molloy ES, Singhal AB, Calabrese LH. Tumour-like mass lesion: an under-recognised presentation of primary angiitis of the central nervous system. Ann Rheum Dis. 2008;67(12):1732-5.

30. Kraemer M, Berlit P. Primary central nervous system vasculitis: clinical experiences with 21 new European cases. Rheumatol Int. 2011;31(4):463-72.

31. Salvarani C, Brown Jr RD, Calamia KT, Christianson TJ, Huston 3rd J, Meschia JF, et al. Rapidly progressive primary central nervous system vasculitis. Rheumatology (Oxford). 2011;50(2):349-58.

32. Chenevier F, Renoux C, Marignier R, Durand-Dubief F, Hermier M, Streichenberger N, et al. Primary angiitis of the central nervous system: response to mycophenolate mofetil. J Neurol Neurosurg Psychiatry. 2009;80(10):1159-61. 
33. Salvarani C, Brown RD, Christianson TJ, Huston J, 3rd, Giannini C, Miller DV, et al. Adult primary central nervous system vasculitis treatment and course: analysis of 163 patients. Arthritis \& rheumatology. 2015.

34. Vera-Lastra O, Sepulveda-Delgado J, Cruz-Dominguez Mdel P, Medina G, Casarrubias-Ramirez M, MolinaCarrion LE, et al. Primary and secondary central nervous system vasculitis: clinical manifestations, laboratory findings, neuroimaging, and treatment analysis. Clin Rheumatol. 2015;34(4):729-38.

35. Alhaboob AA, Hasan GM, Malik MA, Rehman MZ. Therapeutic benefits and side effects of azathioprine and aspirin in treatment of childhood primary arterial stroke. Ann Neurosci. 2014;21(1):10-3.

36. Kitchen L, Westmacott R, Friefeld S, MacGregor D, Curtis R, Allen A, et al. The pediatric stroke outcome measure: a validation and reliability study. Stroke. 2012;43(6):1602-8.

37. Swartz RH, Bhuta SS, Farb RI, Agid R, Willinsky RA, Terbrugge KG, et al. Intracranial arterial wall imaging using high-resolution 3-tesla contrast-enhanced MRI. Neurology. 2009;72(7):627-34.

38. Batthish M, Banwell B, Laughlin S, Halliday W, Peschken C, Paras E, et al. Refractory primary central nervous system vasculitis of childhood: successful treatment with infliximab. J Rheumatol.

2012;39(11):2227-9.

39. Cellucci T, Tyrrell PN, Sheikh S, Benseler SM. Childhood primary angiitis of the central nervous system: identifying disease trajectories and early risk factors for persistently higher disease activity. Arthritis Rheum. 2012;64(5):1665-72.

40. Verhey LH, Branson HM, Shroff MM, Callen DJ, Sled JG, Narayanan S, et al. MRI parameters for prediction of multiple sclerosis diagnosis in children with acute CNS demyelination: a prospective national cohort study. Lancet Neurol. 2012;10(12):1065-73.

41. Venkateswaran S, Hawkins C, Wassmer E. Diagnostic yield of brain biopsies in children presenting to neurology. J Child Neurol. 2008;23(3):253-8.

42. Ford-Jones EL, Macgregor D, Richardson S, Jamieson F, Blaser S, Artsob H. Acute childhood encephalitis and meningoencephalitis: diagnosis and management. Paediatr Child Health. 1998;3(1):33-40.

43. Askalan R, Laughlin S, Mayank S, Chan A, MacGregor $\mathrm{D}$, Andrew M, et al. Chickenpox and stroke in childhood: a study of frequency and causation. Stroke. 2001;32(6):1257-62.

44. Gilden DH, Kleinschmidt-DeMasters BK, LaGuardia JJ, Mahalingam R, Cohrs RJ. Neurologic complications of the reactivation of varicella-zoster virus. $N$ Engl J Med. 2000;342(9):635-45.

45. Kleinschmidt-DeMasters BK, Gilden DH. VaricellaZoster virus infections of the nervous system: clinical and pathologic correlates. Arch Pathol Lab Med. 2001;125(6):770-80.

46. Ueno M, Oka A, Koeda T, Okamoto R, Takeshita K. Unilateral occlusion of the middle cerebral artery after varicella-zoster virus infection. Brain Dev. 2002;24(2):106-8.

47. Nogueras C, Sala M, Sasal M, Vinas J, Garcia N, Bella $\mathrm{MR}$, et al. Recurrent stroke as a manifestation of primary angiitis of the central nervous system in a patient infected with human immunodeficiency virus. Arch Neurol. 2002;59(3):468-73.

48. Muller M, Wandel S, Colebunders R, Attia S, Furrer H, Egger $\mathrm{M}$, et al. Immune reconstitution inflammatory syndrome in patients starting antiretroviral therapy for HIV infection: a systematic review and meta-analysis. Lancet Infect Dis. 2010;10(4):251-61.

49. Pomper MG, Miller TJ, Stone JH, Tidmore WC, Hellmann DB. CNS vasculitis in autoimmune disease: MR imaging findings and correlation with angiography. AJNR Am J Neuroradiol. 1999;20(1):75-85.

50. Rossi CM, Di Comite G. The clinical spectrum of the neurological involvement in vasculitides. J Neurol Sci. 2009;285(1-2):13-21.

51. Seror R, Mahr A, Ramanoelina J, Pagnoux C, Cohen P, Guillevin L. Central nervous system involvement in Wegener granulomatosis. Medicine (Baltimore). 2006;85(1):54-65.

52. von Scheven E, Lee C, Berg BO. Pediatric Wegener's granulomatosis complicated by central nervous system vasculitis. Pediatr Neurol. 1998;19(4):317-9.

53. Nishino H, Rubino FA, DeRemee RA, Swanson JW, Parisi JE. Neurological involvement in Wegener's granulomatosis: an analysis of 324 consecutive patients at the Mayo Clinic. Ann Neurol. 1993;33(1):4-9.

54. Mukhtyar C, Guillevin L, Cid MC, Dasgupta B, de Groot K, Gross W, et al. EULAR recommendations for the management of primary small and medium vessel vasculitis. Ann Rheum Dis. 2009;68(3):310-7.

55. Nadeau SE. Neurologic manifestations of systemic vasculitis. Neurol Clin. 2002;20(1):123-50. vi.

56. Moshous D, Feyen O, Lankisch P, Schwarz K, Schaper J, Schneider M, et al. Primary necrotizing lymphocytic central nervous system vasculitis due to perforin deficiency in a four-year-old girl. Arthritis Rheum. 2007;56(3):995-9.

57. Perry MC, Harrison Jr EG, Burgert Jr EO, Gilchrist GS. Familial erythrophagocytic lymphohistocytosis. Report of two cases and clinicopathologic review. Cancer. 1976;38(1):209-18.

58. Gupta S, Weitzman S. Primary and secondary hemophagocytic lymphohistiocytosis: clinical features, pathogenesis and therapy. Expert Rev Clin Immunol. 2010;6(1):137-54.

59. Deiva K, Mahlaoui N, Beaudonnet F, de Saint BG, Caridade G, Moshous D, et al. CNS involvement at the onset of primary hemophagocytic lymphohistiocytosis. Neurology. 2012;78(15):1150-6. 
60. Henter JI, Arico M, Egeler RM, Elinder G, Favara BE, Filipovich AH, et al. HLH-94: a treatment protocol for hemophagocytic lymphohistiocytosis. HLH study Group of the Histiocyte Society. Med Pediatr Oncol. 1997;28(5):342-7.

61. Amano S, Hazama F. Neutral involvement in Kawasaki disease. Acta Pathologica Japonica. 1980;30(3):365-73.

62. De Felice KM, Novotna M, Enders FT, Faubion WA, Tremaine WJ, Kantarci OH, et al. Idiopathic inflammatory demyelinating disease of the central nervous system in patients with inflammatory bowel disease: retrospective analysis of 9095 patients. Aliment Pharmacol Ther. 2015;41(1):99-107.

63. Gobron C, Kaci R, Sokol H, Vahedi K, Lejoyeux P, Guillaud C, et al. Unilateral carotid granulomatous arteritis and Crohn's disease. Rev Neurol. 2010;166(5):542-6.

64. Garge SS, Vyas PD, Modi PD, Ghatge S. Crohns disease with central nervous system vasculitis causing subarachnoid hemorrhage due to aneurysm and cerebral ischemic stroke. Ann Indian Acad Neurol. 2014;17(4):444-7.

65. Singhal AB, Hajj-Ali RA, Topcuoglu MA, Fok J, Bena J, Yang D, et al. Reversible cerebral vasoconstriction syndromes: analysis of 139 cases. Arch Neurol. 2011.

66. Aoki S, Hayashi N, Abe O, Shirouzu I, Ishigame K, Okubo T, et al. Radiation-induced arteritis: thickened wall with prominent enhancement on cranial MR images report of five cases and comparison with 18 cases of Moyamoya disease. Radiology. 2002;223(3):683-8.

67. Ma M, Barnes G, Pulliam J, Jezek D, Baumann RJ, Berger JR. CNS angiitis in graft vs host disease. Neurology. 2002;59(12):1994-7.

68. Sostak P, Padovan CS, Eigenbrod S, Roeber S, Segerer S, Schankin C, et al. Cerebral angiitis in four patients with chronic GVHD. Bone Marrow Transplant. 2010;45(7):1181-8.

69. Zhou Q, Yang D, Ombrello AK, Zavialov AV, Toro C, Zavialov AV, et al. Early-onset stroke and vasculopathy associated with mutations in ADA2. N Engl J Med. 2014;370(10):911-20.

70. Navon Elkan P, Pierce SB, Segel R, Walsh T, Barash J, Padeh S, et al. Mutant adenosine deaminase 2 in a polyarteritis nodosa vasculopathy. N Engl J Med. 2014;370(10):921-31.

71. Liu Y, Jesus AA, Marrero B, Yang D, Ramsey SE, Montealegre Sanchez GA, et al. Activated STING in a vascular and pulmonary syndrome. $\mathrm{N}$ Engl J Med. 2014;371(6):507-18.

72. Crow YJ, Vanderver A, Orcesi S, Kuijpers TW, Rice GI. Therapies in Aicardi-Goutieres syndrome. Clin Exp Immunol. 2014;175(1):1-8.

73. Ramantani G, Niggemann P, Bast T, Lee-Kirsch MA. Reconciling neuroimaging and clinical findings in Aicardi-Goutieres syndrome: an autoimmune-mediated encephalopathy. AJNR Am J Neuroradiol. 2010;31(7):E62-3. author reply E4.

74. Witt KA, Sandoval KE. Steroids and the blood-brain barrier: therapeutic implications. Adv Pharmacol. 2014;71:361-90.

75. Said G. Treatment of neurological disorders with intravenous immunoglobulins. Malden MA, editor. London: Blackwell Science; 2000.

76. Randomised trial of plasma exchange, intravenous immunoglobulin, and combined treatments in Guillain-Barre syndrome. Plasma Exchange/ Sandoglobulin Guillain-Barre Syndrome Trial Group. Lancet. 1997;349(9047):225-30.

77. Golumbek P. Pharmacologic agents for pediatric neuroimmune disorders. Semin Pediatr Neurol. 2010;17(4):245-53.

78. Toussirot E, Bereau M. The risk of progressive multifocal leukoencephalopathy under biological agents used in the treatment of chronic inflammatory diseases. Inflamm Allergy Drug Targets. 2014;13(2):121-7.

79. Szpirt WM, Heaf JG, Petersen J. Plasma exchange for induction and cyclosporine A for maintenance of remission in Wegener's granulomatosis-a clinical randomized controlled trial. Nephrol Dial Transplant Off Publ Eur Dial Transplant Assoc Eur Ren Assoc. 2011;26(1):206-13.

80. Weber SC, Uhlenberg B, Raile K, Querfeld U, Muller D. Polyoma virus-associated progressive multifocal leukoencephalopathy after renal transplantation: regression following withdrawal of mycophenolate mofetil. Pediatr Transplant. 2011;15(2):E19-24. 